\title{
Extreme Drought: Summary of Hydrologic Conditions in Georgia, 2011
}

The United States Geological Survey (USGS) Georgia Water Science Center (GaWSC) maintains a long-term hydrologic monitoring network of more than 320 realtime streamgages, including 10 real-time lake-level monitoring stations and 63 realtime water-quality monitors. Additionally, the GaWSC operates more than 180 groundwater wells, 35 of which are real-time. One of the many benefits from this monitoring network is that the data analyses provide an overview of the hydrologic conditions of rivers, creeks, reservoirs, and aquifers in Georgia.

Streamflow data are verified throughout the year by USGS hydrographers, and this information is available to water-resource managers, recreationalists, and Federal, State, and local agencies. Hydrologic conditions are determined by comparing the results of statistical analyses of the data collected during the current water year ${ }^{1}$ (WY) to historical data collected over the period of record. Changing hydrologic conditions emphasize the need for accurate, timely data to help Federal, State and local officials make informed decisions regarding the management and conservation of Georgia's water resources for agricultural, recreational, ecological, and water-supply needs and for use in protecting life and property.

On August 31, 2011, the Office of the State Climatologist reported extreme drought conditions in almost all areas of Georgia south of the Georgia mountains and that all counties in Georgia were classified as being in moderate, severe, or extreme drought. Also reported were soil moistures at the fifth percentile, indicating that, statistically, soils would have more moisture 95 out of 100 years based on historical data. Wildfire danger was rated from high to extreme by the Georgia Forestry Commission, and in August 2011 Georgia had twice as many acres of scorched land compared to the long-term August average (Stooksbury, 2011). The GaWSC network reported several streamgages with 20 or more years of record experiencing record low flows, including 02202500 Ogeechee River near Eden, Ga., 02226000 Altamaha River at Doctortown, Ga., and 02353000 Flint River at Newton, $\mathrm{Ga}$. Also, several streamgages recorded no

${ }^{1}$ Water year is the period October 1 through September 30 and is designated by the year in which it ends. For example, the 2011 water year began on October 1, 2010, and ended on September 30, 2011. flow for several days, including 02314500 Suwanee River at U.S. 441 at Fargo, Ga., for only the fifth time in 79 years of record.

\section{Streamflow and Groundwater Data}

Daily, monthly, and yearly streamflow and groundwater statistics from the 2011 USGS annual data report (ADR;
U.S. Geological Survey, 2012a) were used to develop this summary. Data for WYs 1999-2011 can be accessed online at http://ga.water.usgs.gov/publications/ pubswdr.html. At this Web site, a digital map allows the user to search for current and historical data and graphics collected as part of the USGS monitoring network.

\section{Quarterly Hydrologic Conditions in Georgia for 2011 WY, Based on Drainage Basin Runoff}

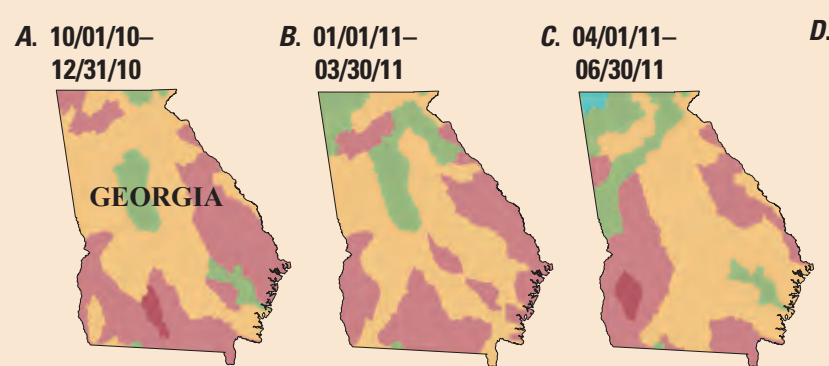

These maps represent hydrologic conditions during the 2011 WY compared to available historical data. The colors represent runoff (flow per unit area) as a percentile of long-term averages. Runoff was calculated for each basin and assumed to be uniform over the entire basin area. Only streamflow stations with a complete daily-flow dataset for the 2011 WY were used (U.S. Geological Survey, 2012c). For the first quarter of the 2011 WY (October-December 2010), much of the State was observing "below normal" and "much below normal" runoff conditions as a result of extreme temperatures and lack of precipitation during the preceding summer months of the 2010 WY $(A)$. Little to no precipitation kept the majority of the State in drought during the second and third quarter of the $2011 \mathrm{WY}(B, C)$. After receiving 50-75 percent of normal precipitation from central Georgia to Florida during the 2011 WY, the majority of the State was in an extreme drought during the fourth quarter as runoff was "much below normal," and large areas of the State observed some of the lowest runoff conditions on record (D).

\section{New Minimum Streamflows}

In 2011, new record-low monthly discharge occurred at 52 of 113 streamgages that have 20 or more years of data. These 52 streamgages are
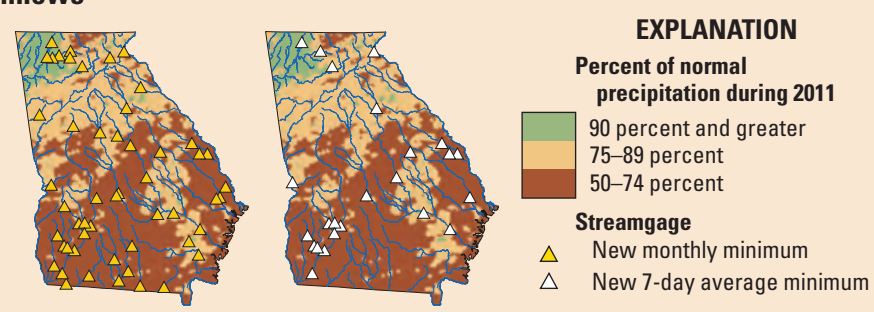

located throughout Georgia. Most of the State received lower-than-normal precipitation; from central Georgia to Florida, the State received $50-75$ percent of normal precipitation. Normal is defined as a 30-year average for 1971-2000.

New record-low 7-day average discharge occurred at 24 of 113 streamgages that have 20 or more years of data in 2011. The majority of these streamgages were located in southern Georgia. 


\section{Chattooga River at Summerville, Ga. 02398000}

The Chattooga River flows in the northwestern corner of Georgia and into Alabama where it flows into Weiss Lake (U.S. Geological Survey, 1975). The northwestern corner of Georgia received 90-110 percent of normal precipitation in the 2011 WY. Daily discharge and 7-day average streamflow for the 2011 WY was predominately in the "normal" range.
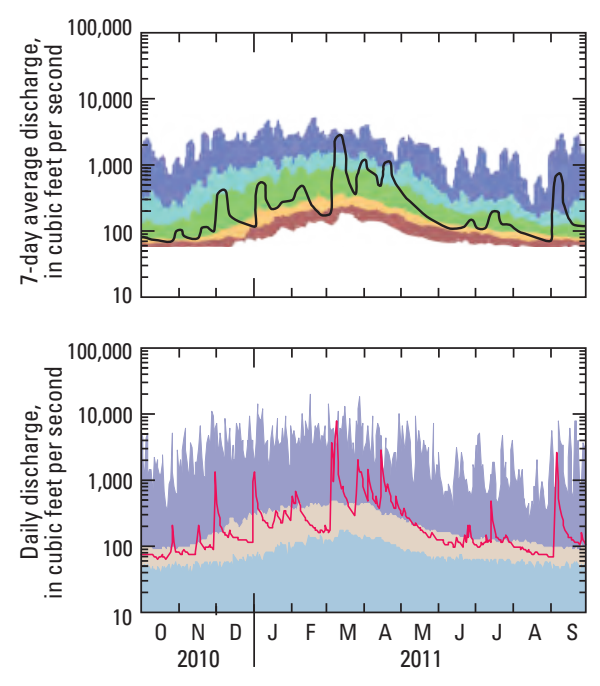

\section{Ocmulgee River at Macon, Ga. 02213000}

The 0 cmulgee River flows out of Jackson Lake and joins the Oconee River to form the Altamaha River (U.S. Geological Survey, 1975). The 7-day average streamflows were mostly in the normal range from 0ctober through March. After an extended period of lower-than-normal precipitation, streamflows were "much below normal" for the remainder of the 2011 WY and came close to setting new record lows. Daily discharge remained near historical median flows for most of the 2011 water year.
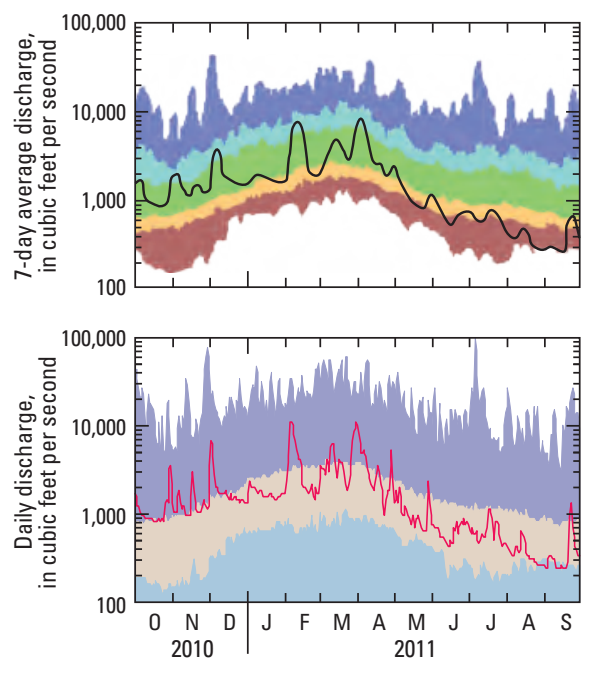

\section{Daily Discharge and 7-Day Average Streamflow Conditions, 2011 Water Year}

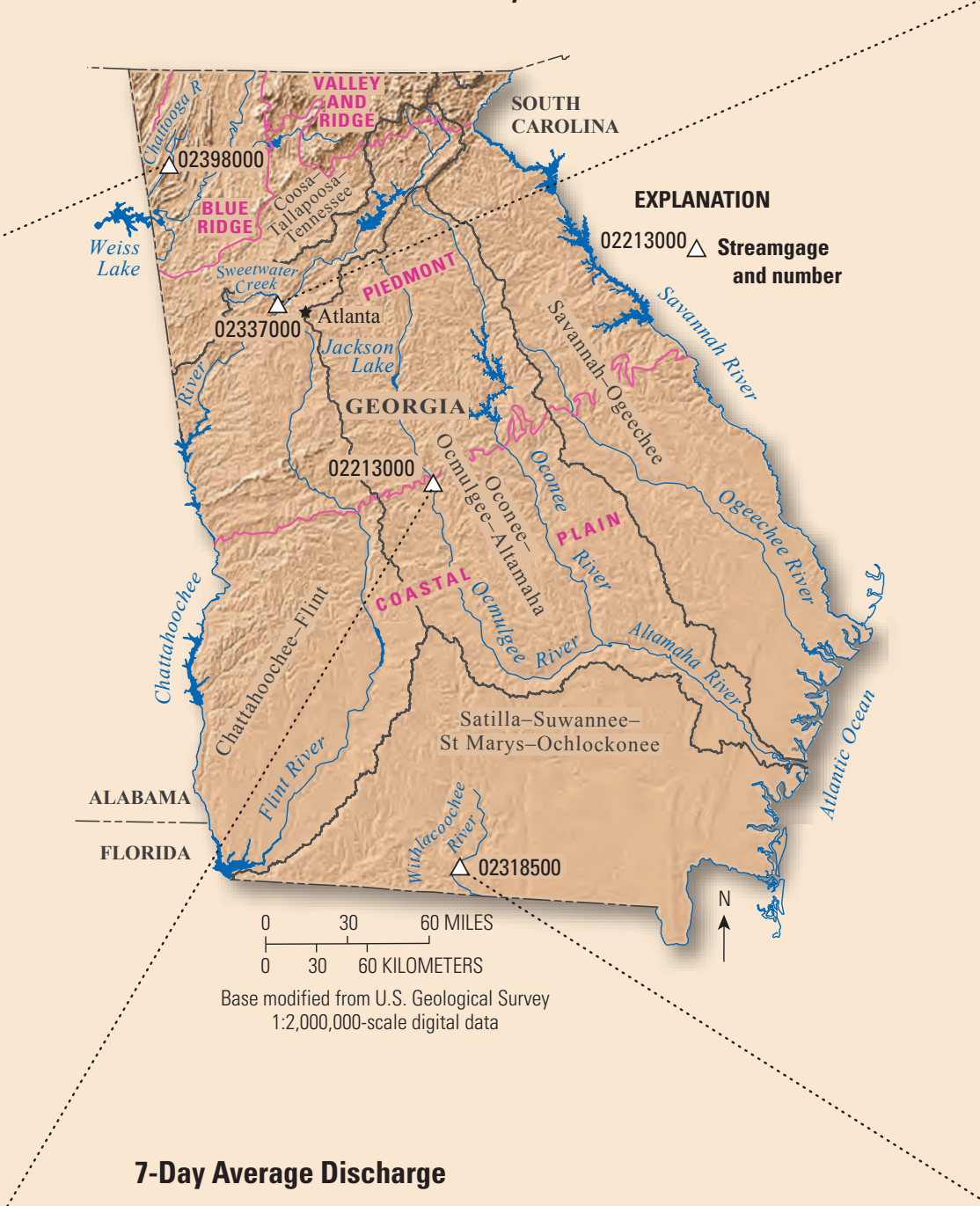

Hydrographs show 2011 daily-mean streamflow, in cubic feet per second, as compared to historical minimum and median streamflow for the entire period of record (U.S. Geological Survey, 2012a).

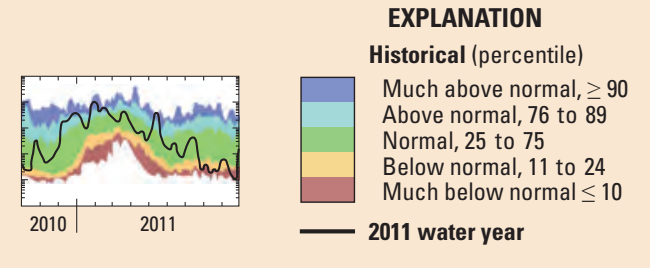

\section{Daily Discharge}

Hydrographs show the 7-day average for 2011 as compared to historical 7-day averages. Data are categorized in percentile ranges from "much above normal" (greater than the 90th percentile) to "much below normal" (less than the 10th percentile) (U.S. Geological Survey, 2012a).

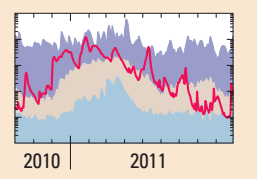

\section{EXPLANATION}

Historical daily flow

Maximum

Median

Minimum

2011 daily mean 


\section{Sweetwater Creek near Austell, Ga. 02337000}

Sweetwater Creek is a major tributary of the Chattahoochee River (U.S. Geological Survey, 1975). The 7-day average streamflow fluctuated between "normal" and "much below normal" from October through April gradually declining to "much below normal" during the latter part of the $2011 \mathrm{WY}$ as the area received 10-20 percent below-normal precipitation. Several daily discharges reached new record lows during the months of August and September.
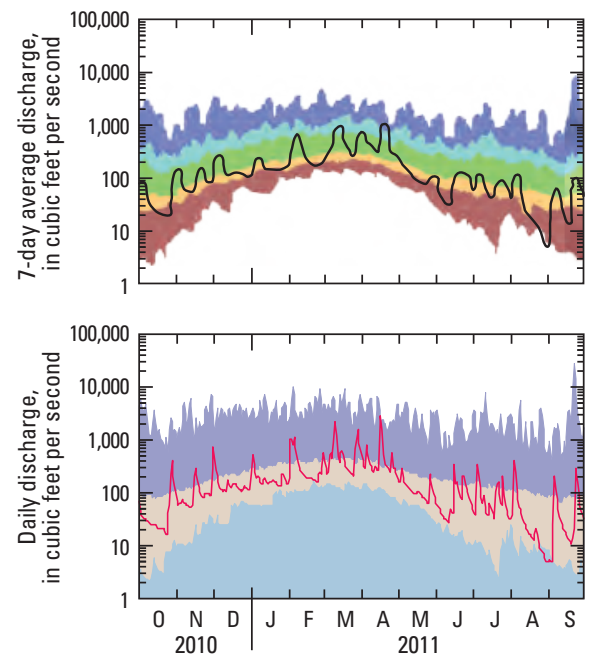

\section{Withlacoochee River at US 84 near Quitman, Ga. 02318500}

The Withlacoochee River flows in the Ochlockonee River basin in the southern coastal plain of Georgia (U.S. Geological Survey, 1975). For most of the 2011 WY, 7-day average streamflow conditions were "below normal" to "much below normal" and came close to the record low recorded in 1940. Several daily discharges reached new record lows during the months of January, May, June, July, August, and September.
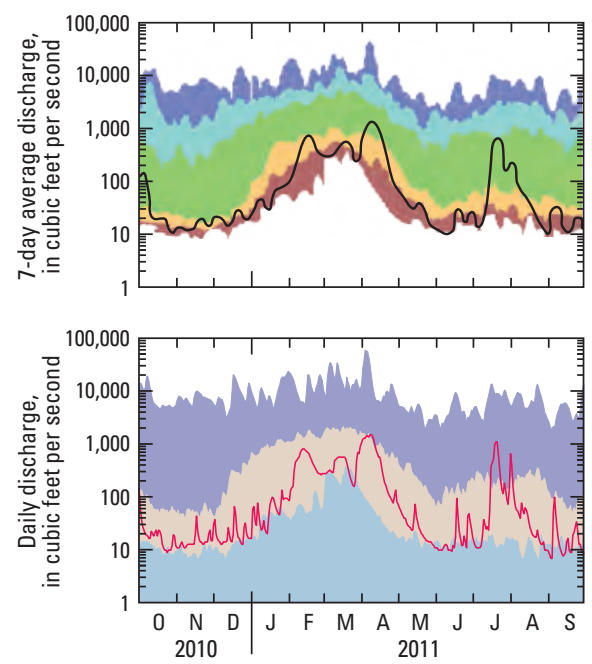

\section{Climate Response Network}

The USGS maintains a network of groundwater wells to monitor the effects of droughts and other climate variability on groundwater levels. These wells are part of the Climate Response Network, which is designed to measure the effects of climate on groundwater levels in unconfined aquifers or near-surface confined aquifers where pumping or other human influences on groundwater levels are minimal (U.S. Geological Survey, 2007, 2012b). The national network consists of about 130 wells, of which 15 are located in Georgia. These wells are monitored as part of the USGS Groundwater Resources and Cooperative Water Programs. Current conditions of groundwater wells in the Climate Response Network can be accessed online at http://groundwaterwatch.usgs.gov. The hydrographs presented are for selected wells in Georgia with at least 5 years of continuous data.

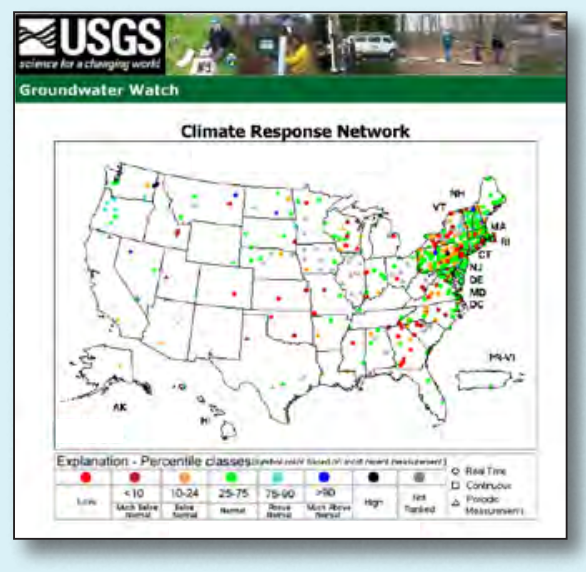

Well 03PP01 is in Walker County in northwestern Georgia and is completed in the valley and ridge aquifer in the Chickamauga limestone. Water storage is in the regolith, primary openings, and secondary fractures and solution openings in rock (Peck and others, 2011).

Water levels are influenced mainly by precipitation and local pumping (Cressler, 1964). The water level in well 03PP01 responds to seasonal change similarly to streamflow at the nearby streamgage on Lookout Creek near New England, Ga. (03568933), which indicates atmospheric, surface-water, and groundwater interactions. The water level in well 03PP01 was near the historical daily median for much of the 2011 WY. 


\section{Georgia's Climate Response Network}

The hydrographs presented are for selected wells in Georgia with at least five years of continuous data. 03568933

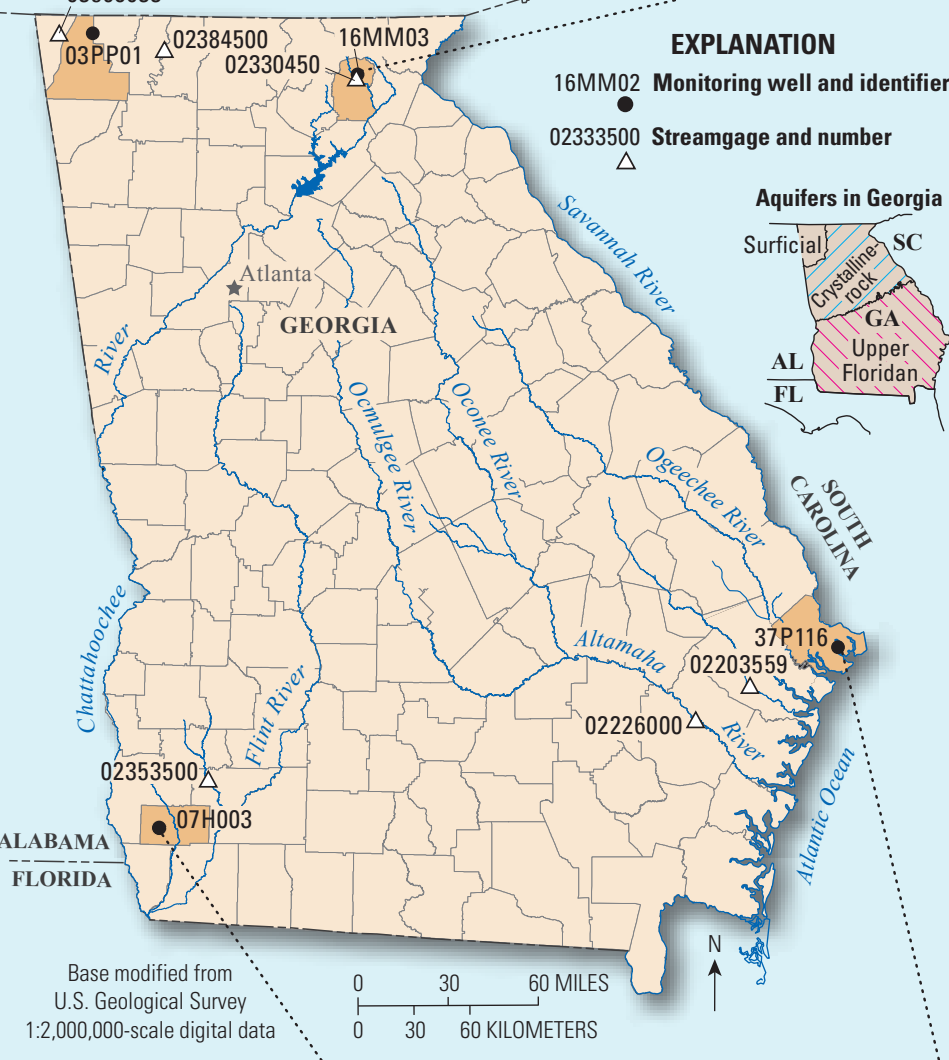

Well 07H0O3 is in Miller County in southwestern Georgia and is completed in the surficial aquifer, which is an unconfined aquifer in this area (Peck and others, 2011). The water level in this well generally rises rapidly during wet periods and declines slowly during dry periods. The water level in well $07 \mathrm{H0O3}$ responds to seasonal change similarly to streamflow at the nearby streamgage on Ichawaynochaway

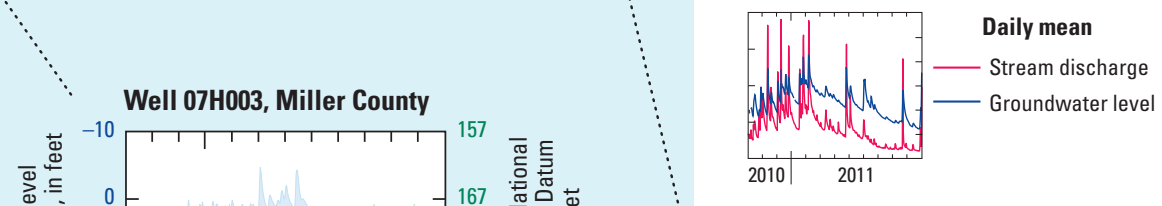

EXPLANATION

in White County northeastern Georgia and is completed in the crystalline-rock aquifer. Water is stored in the regolith and fractures, and the water level is affected by precipitation and evapotranspiration (Cressler and others, 1983). Precipitation can cause a rapid water-level rise in wells tapping aquifers overlain by thin regolith (Peck and others, 2011). The water level in well 16MM03 responds to seasonal change similarly to streamflow at the nearby streamgage on Chattahoochee River at Helen, Ga. (02330450), which indicates atmospheric, surfacewater, and groundwater interactions. The water level in well 16MM03 remained below the historical daily median for much of the 2011 WY.
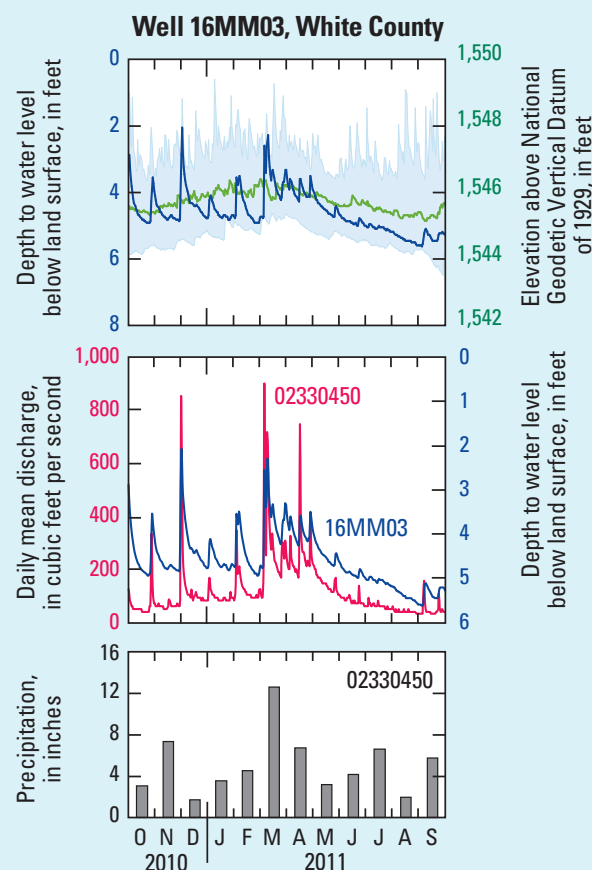

EXPLANATION

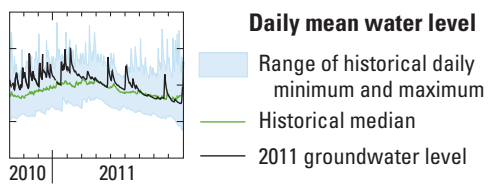

Creek at Milford, Ga. (02353500), which indicates atmospheric, surface-water, and groundwater interactions. In the $2011 \mathrm{WY}$, water levels in well $07 \mathrm{H} 003$ were below the historical daily median for much of the year. For a brief period in January 2011, the daily mean water level fell below the historical daily minimum water level.

Well 37P116 is in Chatham County in southeastern Georgia and is completed in the surficial aquifer. Water levels in this well generally rise rapidly during wet periods and decline slowly during dry periods. The water level in well 37P116 responds to seasonal change similarly to streamflow at the nearby streamgage on Peacock Creek near McIntosh, Ga. (02203559), which indicates atmospheric, surfacewater, and groundwater interactions. The water level in well 37P116 fluctuated above and below the historical daily minimum for most of the 2011 WY.
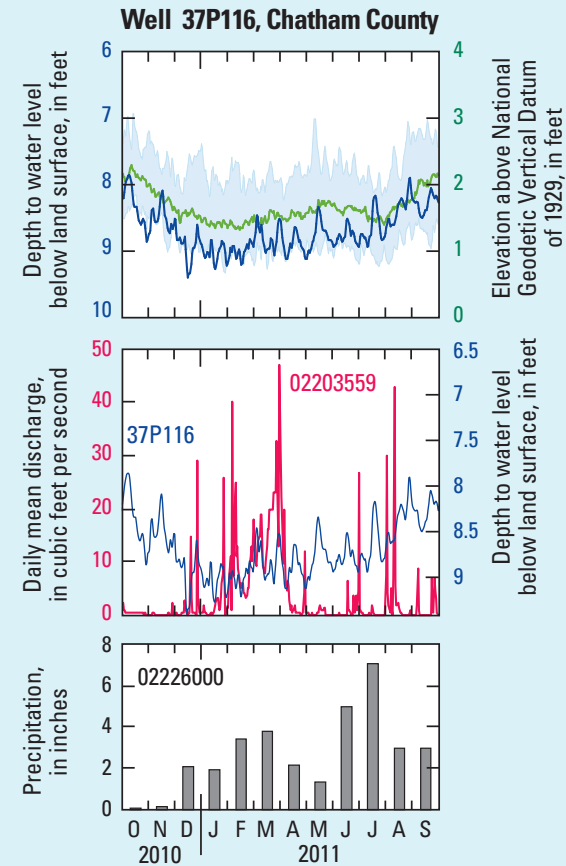


\section{Lakes and Reservoirs}

Major lakes and reservoirs throughout Georgia are managed primarily by the U.S. Army Corps of Engineers and Georgia Power Company to provide water for public and industrial use, flood protection, power generation, wildlife management, and recreation. Managing lakes and reservoirs requires computer models that rely on USGS data to predict changes in climate and water demands.

Lake Sidney Lanier on the Chattahoochee River is the primary drinking-water source for the Atlanta metropolitan area. Lake Sidney Lanier is the most upstream reservoir in a series of reservoirs that include West Point Lake, Walter F. George Lake, and Lake Seminole. Lake Lanier had 24 percent more outflow than inflow during the $2011 \mathrm{WY}$, and the lake elevation fell nearly 10 feet from April through September. The water-level elevation of West Point Lake remained near the top of conservation pool until May when the lake level dropped nearly 6 feet during the remainder of the WY. West Point Dam provides flood protection and hydroelectric power to Troup County, and its construction was authorized by the Flood Control Act of 1962 (U.S. Army Corps of Engineers, 2012c).

Hartwell Lake is on the border between Georgia and South Carolina on the Savannah and Tugaloo Rivers. Hartwell Lake is the most upstream major reservoir on the Savannah River. Water is released to the downstream reservoirs, Richard B. Russell and J. Strom Thurmond. These three lakes on the Savannah River are managed by the U.S. Army Corps of Engineers for water supply, power generation, and water-quality needs of the Savannah River from below Thurmond Dam to Savannah, Ga., and the Atlantic Ocean (U.S. Army Corps of Engineers, 2012a). Hartwell Lake reached full pool after having nearly 2.4 times more inflow than outflow in March but then dropped nearly 8 feet from May through September as outflow was 1.7 times greater than inflow.

Allatoona Lake is on the Etowah River and is managed by the U.S. Army Corps of Engineers. During the 2011 WY, Allatoona Lake remained above or just below the top of conservation pool from October through June. By the end of the $2011 \mathrm{WY}$, the lake level was nearly 7 feet below the top of conservation pool, as outflow was 2.4 times greater than inflow from July through September.
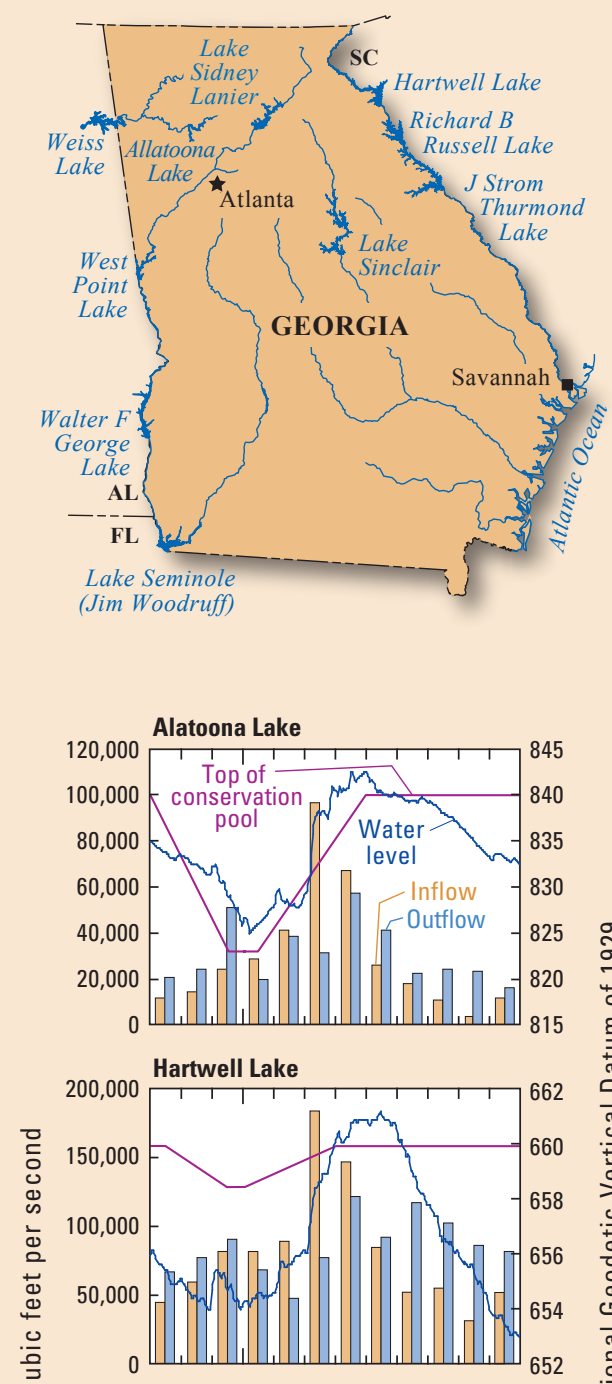

Lake Sidney Lanier

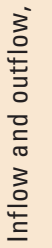

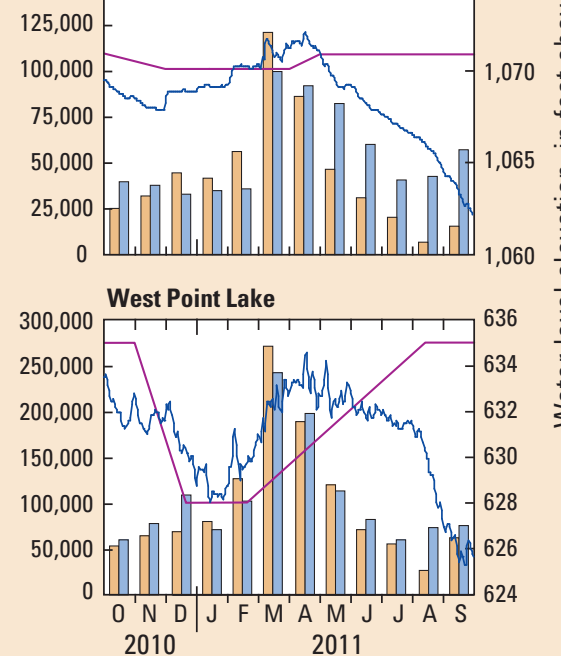

Water-Quality Monitoring in Georgia in Cooperation with the Georgia Department of Natural Resources Environmental Protection Division (EPD)

The USGS, in cooperation with the Georgia Department of Natural Resources Environmental Protection Division (GaEPD), collects nearly 1,000 monthly chemical and nutrient samples and about 800 fecal coliform samples at 49 long-term monitoring stations across the State in addition to data from 3 continuous water-quality monitors. Four fecal coliform samples typically are collected within 30 days twice during the May-to-October period when the standard for water contact applies, and then twice during the November-to-April period when the alternate standard applies, which provides the basis for computing the geometric mean fecal coliform density once-quarterly each calendar year. In addition, about 200 qualityassurance samples for all constituents are collected concurrently to verify the accuracy of sampling techniques and analytical methods.

The USGS provides the GaEPD and the public a relevant, nationally consistent database of long-term water-quality data, which assists the GaEPD in meeting its responsibilities under the Clean Water Act, including, (1) identifying the beneficial uses of surface waters within the State, (2) establishing water-quality standards to maintain the full beneficial uses of surface waters, and (3) identifying water bodies where stream standards are not met and beneficial uses are impaired (Grams, 2011). Water-quality data for Georgia streams are available on a publically accessible Web site at http://waterdata. usgs.gov/ga/nwis/qw/.

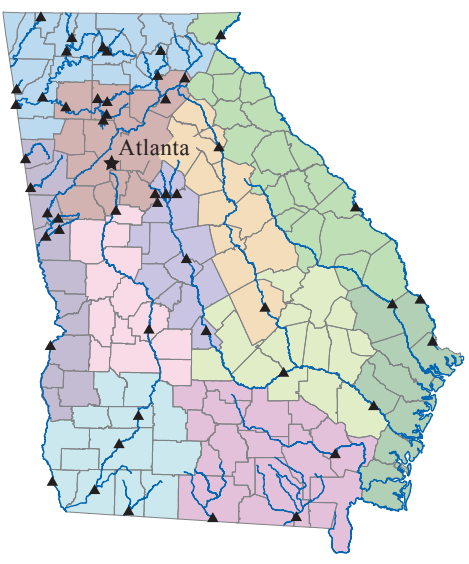

EXPLANATION

Water planning region name

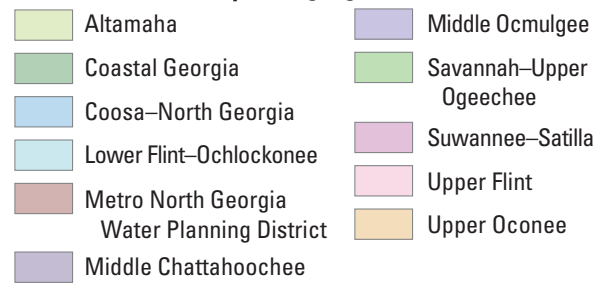

- 2011 USGS-GA EPD discrete OW station 
Water-quantity and quality information are equally important for insuring adequate water availability for human consumption, industrial uses, and aquatic ecosystems. Streamflow conditions are a primary driver of nonpoint-source-related water quality and the most important component affecting water quality in streams (Hirsch and others, 2006).

The USGS-GaEPD discrete water-quality sampling program is designed to collect data systematically, regardless of hydrologic conditions. The graph (top right) shows the water-quality sampling efforts by the USGS at Ogeechee River near Oliver, Ga., during the 2011 WY. Samples were collected throughout the year during periods of high and low discharges.

The relations between water-quality constituents and discharge are shown in the graph. The discrete water-quality sample on February 10 during a period of higher discharge, when compared to samples collected during lower discharge on January 27 and May 26, shows a decline in specific conductance because of the lower amount of dissolved constituents from rainfall runoff. Conversely, non-dissolved constituents, such as total suspended solids and fecal-coliform bacteria, increase with rainfall runoff because these constituents are washed from the land into the stream.

The USGS collected additional water-quality samples at Ogeechee River near Oliver on May 26 after a large fish kill was reported by the GaEPD on May 21, which was believed to have been Columnaris disease, a bacterial disease related to environmental stressors, such as non-point source pollutants (Georgia Environmental Protection Division, 2011b). USGS monitoring data can provide useful information for understanding the water-quality conditions that may be conducive for Columnaris outbreaks and could be used for predicting and possibly avoiding such outbreaks in the future.

The USGS-GaEPD cooperative program collects continuous water-quality data at three sites in Georgia, including USGS station 02337170 Chattahoochee River near Fairburn, Ga. This stream reach is classified as "Fishing" under Georgia Code 391-3-6-.03 "Water Use Classifications and Water Quality Standards," which requires that the daily mean dissolved oxygen (DO) concentrations in the stream remain at or above 5.0 milligrams per liter (Georgia Environmental Protection Division, 2011a). The daily mean DO and daily mean discharge for the Chattahoochee River near Fairburn, Ga., is shown in graph (bottom right) for the $2011 \mathrm{WY}$. No daily mean DO levels fell below the "Fishing" criteria in Georgia streams during the $2011 \mathrm{WY}$.

\section{References}

Cressler, C.W., 1964, Geology and groundwater resources of Walker County, Georgia: Georgia Geologic Survey Information Circular 63, $144 \mathrm{p}$.

Cressler, C.W., Thurmond, C.J., and Hester, W.G., 1983, Groundwater in the greater Atlanta region, Georgia: Georgia Geological Survey Information Circular 63, 15 p. Georgia Department of Natural Resource, Environmental Protection Division, 2011a, Existing rules and corresponding laws, 391-3-6 Water quality control: Accessed July 16, 2012, at http://www.gaepd.org/Documents/rules exist.html.

Georgia Department of Natural Resource, Environmental Protection Division, 2011b, Ogeechee River fish kill information: Accessed July 16, 2012, at http://www.gaepd. org/Documents/ogeecheefishkill.html.

Ogeechee River at Ga. 24, near Oliver, Ga. 02202190

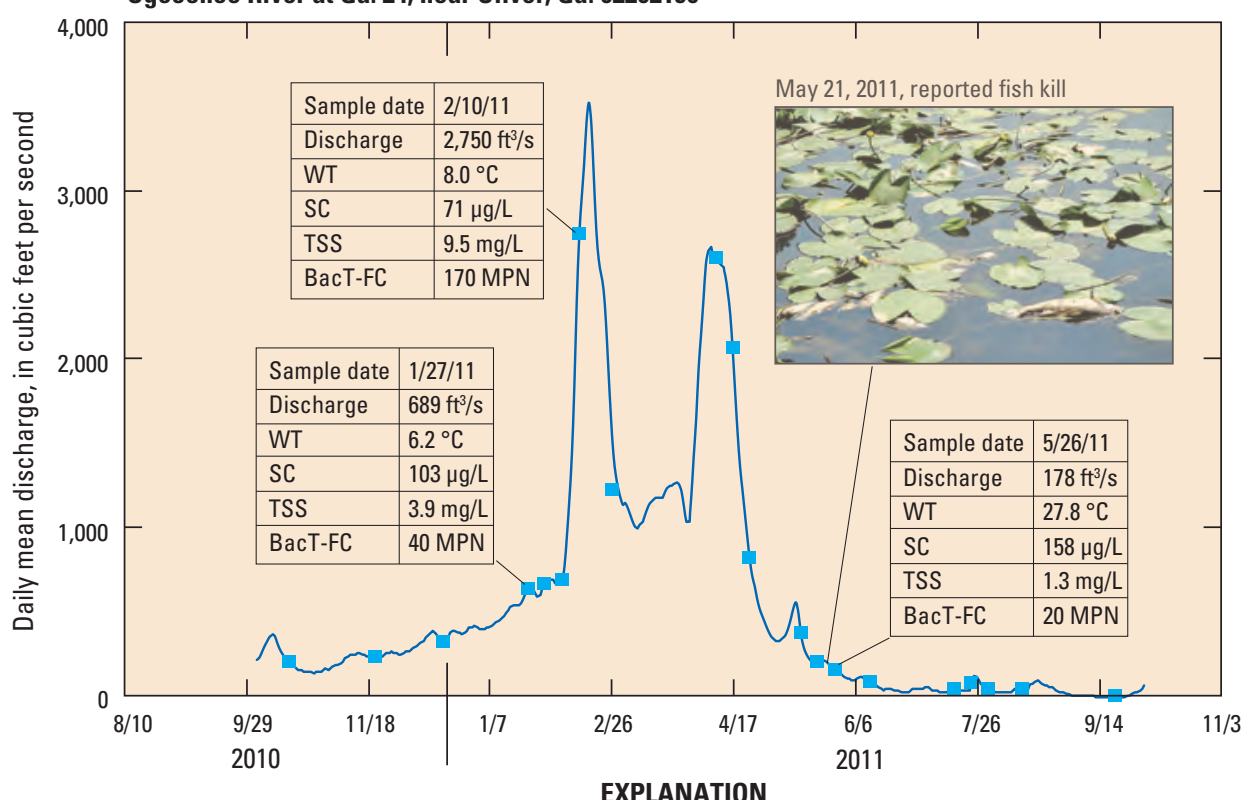

Daily mean discharge

Discrete waterquality sample
Discharge In cubic feet per second $\left(\mathrm{ft}^{3} / \mathrm{s}\right)$

WT Water temperature, in degrees Celsius $\left({ }^{\circ} \mathrm{C}\right)$

SC Specific conductance, in micrograms per liter $(\mu \mathrm{g} / \mathrm{L})$

TSS Total suspended solids, in milligrams per liter ( $\mathrm{mg} / \mathrm{L}$ )

BacT-FC Bacteria, total fecal coliform, most probable number per 100 milliters of water

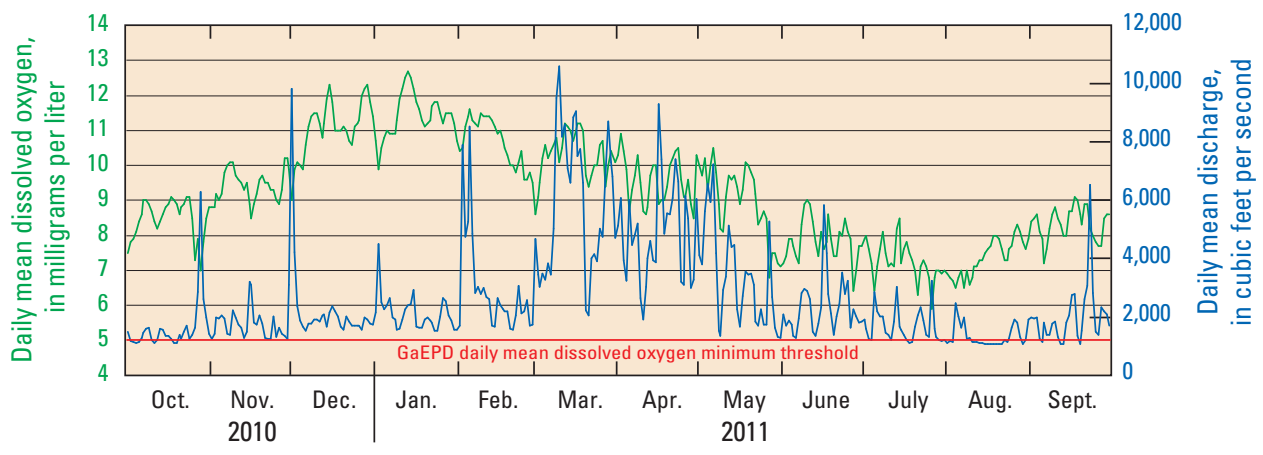

Grams, S.C., 2011, Benefits of long-term water-quality monitoring in Georgia [abs.], in Carroll, G.D., ed., Proceedings of the 2011 Georgia Water Resources Conference, April 11-13, 2011, Athens, Georgia: Georgia Water Resources Institute, 6. Water informatics, 6.1 Watershed data, $1 \mathrm{p}$

Hirsch, R.M., Hamilton, P.A., and Miller, T.L., 2006, U.S. Geological Survey perspective on water-quality monitoring and assessment: Journal of Environmental Monitoring, v. 8, p. 512-518.

Peck, M.F., Painter, J.A., and Leeth, D.C., 2011, Groundwater conditions and studies in Georgia, 2009-2010: U.S. Geological Survey Scientific Investigations Report 2009-5048, 83 p., available at http://pubs usgs.gov/sir/2011/5048/.

National Oceanic and Atmospheric Administration, 2011, National Weather Service advanced hydrologic prediction service, 2011 precipitation maps for Georgia: Accessed June 1, 2012, at http://waterweather.gov

Stooksbury, D.E., 2011, Extreme drought spreads into north Georgia, in News to use about Georgia family, agricultural consumer \& environmental sciences, August 31, 2011: University of Georgia, accessed June 26, 2012, at http://georgiafaces.caes.uga.edu/ index.cfm? public $=$ viewStory \& pk id $=4207$.

Torak, L.J., Painter, J.A., and Peck, M.F., 2010, Geohydrology of the Aucilla-Suwannee-Ochlockonee River Basin, south-central Georgia and adjacent parts of Florida: U.S. Geological Survey Scientific Investigations Report 2010-5072, 78 p.

U.S. Army Corps of Engineers, 2012a, Hartwell Dam \& Lake: U.S. Army Corps of Engineers, Savannah District, accessed June 1, 2012, at http://www.sas.usace. army.mil/lakes/hartwell/.
U.S. Army Corps of Engineers, 2012b, Lake elevations, inflows and outflows: Accessed June 1, 2012, at http://www.sas.usace.army.mil/

U.S. Army Corps of Engineers, 2012c, West Point Lake: U.S. Army Corps of Engineers, Mobile District, accessed June 1, 2012, at http://www.sam.usace.army.mil/ Missions/CivilWorks/Recreation/WestPointLake.aspx.

U.S. Geological Survey, 1975, Hydrologic unit map 1974, State of Georgia: U.S. Geological Survey, scale 1:500,000, 1 sheet.

U.S. Geological Survey, 2007, U.S. Geological Survey Ground-Water Climate Response Network: U.S. Geological Survey Fact Sheet 2007-3003, 4 p., accessed July 1, 2009, at http://pubs.usgs.gov/fs/2007/3003/.

U.S. Geological Survey, 2012a, U.S. Geological Survey annual data report for Georgia, water year 2011: Accessed June 1, 2012, at http://ga.water.usgs.gov/ publications/pubswdr.html.

U.S. Geological Survey, 2012b, U.S. Geological Survey groundwater watch, Climate Response Network: Accessed June 1, 2012, at http://groundwaterwatch.usgs.gov/

U.S. Geological Survey, 2012c, WaterWatch-Current water resources in Georgia: Accessed June 1, 2011, at http://waterwatch.usgs.gov/.

\section{By Andrew E. Knaak, Eric R. Frantz, and} Michael F. Peck

For more information contact: Director, USGS Georgia Water Science Center 3039 Amwiler Road, Suite 130

Atlanta, Georgia 30360

770-903-9100

http://ga.water.usgs.gov/ 